OPEN ACCESS

Edited by:

Teresa Duda,

Salus University, USA

Reviewed by:

Bonnie L. Firestein,

Rutgers, The State University of New Jersey, USA

Nicole Cyr.

Stonehill College, USA

*Correspondence: Karin Tein

Department of Physiology, Institute

of Biomedicine and Translational

Medicine, University of Tartu, 19 Ravila Street, 50411 Tartu, Estonia karin.tein@gmail.com

Received: 01 July 2015 Accepted: 10 August 2015

Published: 25 August 2015

Citation:

Tein K, Kasvandik S, Kõks S, Vasar E and Terasmaa A (2015) Prohormone

convertase 2 activity is increased in the hippocampus of Wfs 1 knockout

Front. Mol. Neurosci. 8:45. doi: 10.3389/fnmol.2015.00045

\section{Prohormone convertase 2 activity is increased in the hippocampus of Wfs1 knockout mice}

\author{
Karin Tein ${ }^{1 *}$, Sergo Kasvandik², Sulev Kõks ${ }^{3,4}$, Eero Vasar ${ }^{1}$ and Anton Terasmaa' \\ ${ }^{1}$ Department of Physiology, Institute of Biomedicine and Translational Medicine, University of Tartu, Tartu, Estonia, \\ ${ }^{2}$ Proteomics core facility, Institute of Technology, University of Tartu, Tartu, Estonia, ${ }^{3}$ Department of Pathophysiology, \\ Institute of Biomedicine and Translational Medicine, University of Tartu, Tartu, Estonia, ${ }^{4}$ Department of Reproductive Biology, \\ Estonian University of Life Sciences, Tartu, Estonia
}

Background: Mutations in WFS1 gene cause Wolfram syndrome, which is a rare autosomal recessive disorder, characterized by diabetes insipidus, diabetes mellitus, optic nerve atrophy, and deafness. The WFS1 gene product wolframin is located in the endoplasmic reticulum. Mice lacking this gene exhibit disturbances in the processing and secretion of peptides, such as vasopressin and insulin. In the brain, high levels of the wolframin protein have been observed in the hippocampus, amygdala, and limbic structures. The aim of this study was to investigate the effect of Wfs1 knockout (KO) on peptide processing in mouse hippocampus. A peptidomic approach was used to characterize individual peptides in the hippocampus of wild-type and Wfs1 KO mice.

Results: We identified 126 peptides in hippocampal extracts and the levels of 10 peptides differed between Wfs1 $\mathrm{KO}$ and wild-type mice at $\mathrm{P}<0.05$. The peptide with the largest alteration was little-LEN, which level was 25 times higher in the hippocampus of Wfs1 KO mice compared to wild-type mice. Processing (cleavage) of little-LEN from the Pcsk1n gene product proSAAS involves prohormone convertase 2 (PC2). Thus, PC2 activity was measured in extracts prepared from the hippocampus of Wfs1 KO mice. The activity of PC2 in Wfs1 mutant mice was significantly higher $(149.9 \pm 2.3 \%, p$ $<0.0001, \mathrm{n}=8)$ than in wild-type mice $(100.0 \pm 7.0 \%, \mathrm{n}=8)$. However, Western blot analysis showed that protein levels of 7B2, proPC2 and PC2 were same in both groups, and so were gene expression levels.

Conclusion: Processing of proSAAS is altered in the hippocampus of Wfs1-KO mice, which is caused by increased activity of PC2. Increased activity of PC2 in Wfs 1 KO mice is not caused by alteration in the levels of PC2 protein. Our results suggest a functional link between Wfs1 and PC2. Thus, the detailed molecular mechanism of the role of Wfs1 in the regulation of PC2 activity needs further investigation.

Keywords: Wfs1, prohormone convertase 2, peptidomics, mass-spectrometry, proSAAS, 7B2, peptide processing

\section{Introduction}

Wolfram syndrome (WS) was first described by Wolfram and Wagener (1938) and is a rare autosomal recessive disorder characterized by diabetes insipidus (DI), diabetes mellitus (DM), optic nerve atrophy (OA), and deafness (D) - DIDMOAD (Strom et al., 1998). WS is caused by mutations in WFS1 gene, which is located in the fourth chromosome 4 p16.1 region. 
Approximately $1 \%$ of the general population are heterozygous carriers of WFS1 gene mutation and it has been found that these carriers have increased risk for developing a psychiatric disease (Swift et al., 1991). Though not all mutations in WFS1 gene cause WS, carriers of WFS1 gene mutations have a 26 times higher risk for psychiatric diseases such as depression and bipolar disorder (Swift and Swift, 2000). Patients without WS, but exhibiting bipolar disease, major depression, and schizophrenia have been found to carry mutations in WFS1 gene (Strom et al., 1998; Evans et al., 2000; Torres et al., 2001; Crawford et al., 2002).

WFS1 gene product is wolframin, a glycoprotein of 890 amino acid residues and molecular weight of about $100 \mathrm{kDa}$ (Strom et al., 1998). Wolframin is mostly found in the brain, heart and pancreatic insulin-producing $\beta$-cells. The highest levels of expression in the brain are found in the hippocampus, amygdala, allocortex and olfactory bulb (Takeda et al., 2001). On an intracellular level, Wfs1 protein is located in the membrane of the endoplasmic reticulum (ER), where it forms $\sim 400 \mathrm{kDa}$ protein complexes (Hofmann et al., 2003). Wolframin influences cellular $\mathrm{Ca}^{2+}$ homeostasis and $\beta$-cell survival (Hofmann et al., 2003). In addition, Wfs 1 protein takes part in the regulation of the ER-stress response (Rigoli et al., 2011).

Human studies have shown that peptide processing is altered in patients with WS. Immunohistochemistry of the autopsy samples reveal that processed vasopressin is absent in the supraoptic and paraventricular nuclei of hypothalamus in patients with WS (Gabreels et al., 1998). This was accompanied by a lack of expression of prohormone convertase 2 (PC2) and the chaperone secretogranin $\mathrm{V}$ (7B2) in this brain region of WS patients (Gabreels et al., 1998). In addition to its localization in the ER membrane, Wfs 1 is also localized in the secretory granules of beta-cells and participates in acidification of these granules (Hatanaka et al., 2011). Conversion of proinsulin to insulin takes place in the secretory granules and is $\mathrm{pH}$ dependent (Hatanaka et al., 2011), thus, lack of Wfs1 results in impaired insulin processing, which is manifested by an increased proinsulin/insulin ratio (Hatanaka et al., 2011; Noormets et al., 2011).

The role of Wfs 1 in the regulation of insulin secretion and survival of pancreatic beta-cells is a topic of ongoing research and has attracted wide attention. On the other hand, there is only one report on the role of WFS1 on the processing of brain peptides (Gabreels et al., 1998). One of the regions in the brain with the highest expression of Wfs 1 is hippocampus (Luuk et al., 2008). Thus, the aim of the present study was to evaluate the processing of neuropeptides in this brain region using a peptidomic approach. We have identified peptides in which processing is altered in the hippocampus of Wfs1 KO mice, and evaluated the activity of peptide processing enzymes that take part in the processing of these peptides.

\section{Materials and Methods}

\section{Wfs1 Knockout Mice}

Test animals were male 129Wfs1 gene mutation mice (129Wfs1KO) and control group animals were male wild-type littermate $(129 \mathrm{WT})$ mice. Animals were kept in polypropylene cages. The air temperature in the room was $21 \pm 2^{\circ} \mathrm{C}$ and light cycle was $12 \mathrm{~h}$ light and $12 \mathrm{~h}$ dark. The light was switched on at $7.00 \mathrm{am}$. Chow and drinking water was available ad libitum. All of the procedures performed with animals were approved by the Estonian National Board of Animal Experiments (No. 86, 28.08.2007) and were in accordance with the European Union directive 86/609/EEC.

Generation of whole body Wfs1 knock out (KO) mouse was described previously (Noormets et al., 2009). Briefly, Wfs1 deficient mice were generated by replacing most of the coding region of the Wfs1 gene (exon8) with LacZ sequence. This results in the deletion of the amino acids 360-890 of the Wfs1 protein and a fusion between remaining Wfs1 fragment and LacZ. The official designation of this strain is Wfs 1 tm1Koks according to the Mouse Genome Database ${ }^{1}$. Mice with the isogenic 129S6 background were used in this study. Genotyping of the mice was performed by multiplex PCR for both alleles using specific primers as described previously (Noormets et al., 2009).

In general, eight Wfs1 $\mathrm{KO}$ and eight wild-type animals were used for each kind of analysis, as different tissue preparation was needed for different experiments. Altogether 96 mice were used in this study.

\section{Tissue Preparation}

At the age of 3 months mice were sacrificed by cervical dislocation. The brain was removed and the hippocampus dissected out on a cold plate. Immediately thereafter tissue samples were frozen in liquid nitrogen and kept at $-80^{\circ} \mathrm{C}$ until the analyses. Body weight of Wfs1 KO mice was smaller compared to wild-type littermates $(22.0 \pm 0.7 \mathrm{~g}$ and $28.3 \pm 0.5 \mathrm{~g}$, respectively; $p<0.0001 ; n=30$ ).

\section{Peptide Extraction}

Peptides were extracted from hippocampal tissue by a double extraction protocol based on Frese et al. (2013). One hundred fifty microliter of acidified acetone (acetone/water/concentrated $\mathrm{HCl}$ 40:6:1) was added to the tissue sample. After microtip sonication, samples were incubated for $1 \mathrm{~h}$ on ice. The samples were then centrifuged for $25 \mathrm{~min}$ at $14,000 \mathrm{~g}\left(4^{\circ} \mathrm{C}\right)$, the supernatant was transferred to a new tube and neutralized by adding $1 \mathrm{M}$ $\mathrm{NaOH}(1: 1$ ratio to $\mathrm{HCl})$. Acetone was evaporated using a vacuum centrifuge. The pellet was washed with $0.25 \%$ acetic acid, incubated on ice for an hour and collected by centrifugation for $25 \mathrm{~min}$ at $14,000 \mathrm{~g}\left(4^{\circ} \mathrm{C}\right)$. The pellet and the supernatant were combined and filtered through a Millipore $10 \mathrm{kDA}$ Amicon Ultra YM-10 membrane for $30 \mathrm{~min}$ at 7,000 g. The filtered peptide extract was desalted using C18 StageTips (Rappsilber et al., 2007) and reconstituted in $0.5 \%$ TFA.

\section{Nano-LC/MS/MS Analysis}

Injected peptides were separated on Ultimate 3000 RSLCyano system (Dionex) using a C18 cartridge trap-column in backflush configuration and an in-house packed ( $3 \mu \mathrm{m}$ C18 material, Dr

\footnotetext{
${ }^{1}$ http://www.informatics.jax.org
} 
MaischGmbh) analytical $50 \mathrm{~cm} \times 75 \mu \mathrm{m}$ emitter-column $(\mathrm{New}$ Objective). Peptides were eluted at $200 \mathrm{nl} / \mathrm{min}$ with a $8-40 \%$ B 90 min gradient (buffer B: $80 \% \mathrm{ACN}+0.1 \%$ FA, buffer A: $0.1 \% \mathrm{FA}$ ) to a $\mathrm{Q}$ Exactive (Thermo Fisher Scientific) tandem mass spectrometer operating with a top-10 strategy and a cycle time of $0.9 \mathrm{~s}$. Briefly, one $350-1400 \mathrm{~m} / \mathrm{z}$ MS scan at a resolution setting of $R=70,000$ was followed by higher-energy collisional dissociation fragmentation (normalized collision energy of 25) of 10 most intense ions $(>+1$ charge state) at $R=17,500$. Dynamic exclusion was limited to $40 \mathrm{~s}$. An example of chromatogram and mass spectrum are presented on Figure 1.

\section{Raw Data Analysis}

Raw data was processed with MaxQuant 1.4.0.8 software package (Cox and Mann, 2008). Methionine oxidation and protein N-terminal acetylation were set as variable modifications. Search was performed against UniProt ${ }^{2}$ mouse neuropeptides database (March 2014) using unspecific digestion rule. MS and MS/MS mass errors were 4.5 and $20 \mathrm{ppm}$, respectively. Only peptides minimally six amino acids long were accepted and transfer of identifications between runs was allowed. Peptide-spectrum match and protein FDR was kept below $1 \%$ using a target-decoy approach. All other parameters were default.

Raw intensity values for each sample were summed up and intensity value for each peptide in this sample was normalized for the sum. Normalized values were analyzed using Student's $t$-test. $P$-value of less than 0.05 was considered as statistically significant.

${ }^{2}$ www.uniprot.org

A

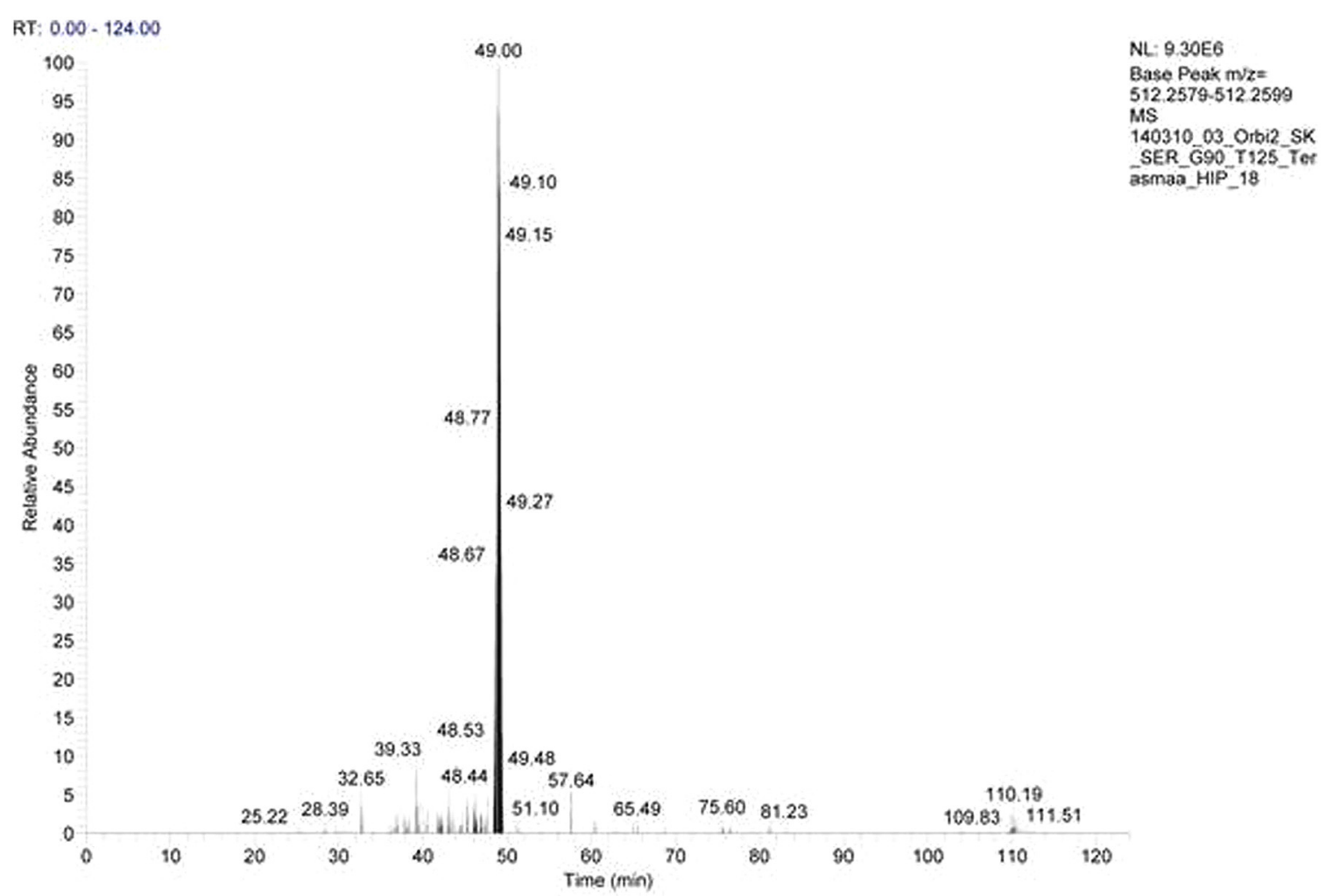

B

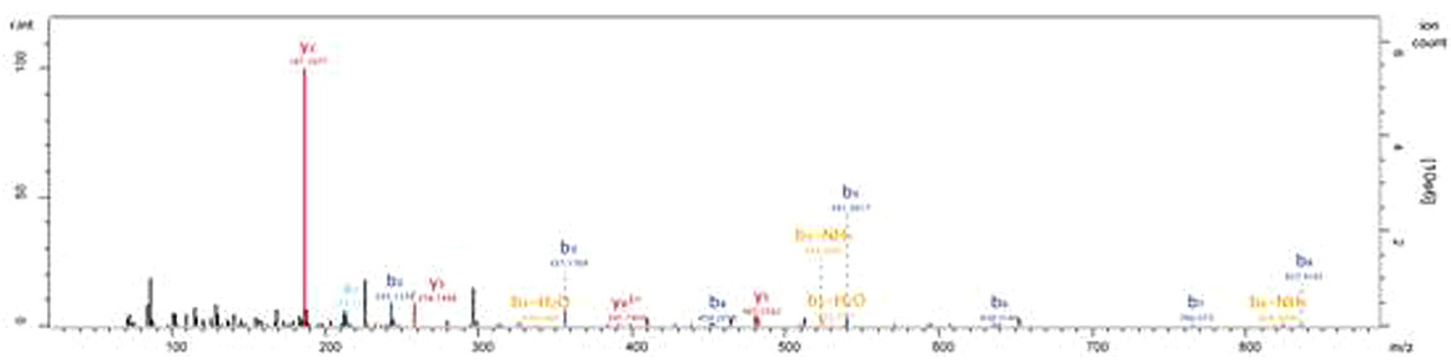

FIGURE 1 | An example of an extracted chromatogram (A) and MS/MS spectrum (B) of peptide LENPSPQAPA (little-LEN). The b- and y-series ions are annotated on the MS/MS spectrum. 


\section{Enzymatic Activity of PC2}

The method is based on measuring the liberation of aminocoumarin using a fluorescence spectrophotometer developed by $\mathrm{Li}$ et al. (2003). Aminocoumarin is cleaved from the fluorogenic substrate pGlu-Arg-Thr-Lys-Arg-AMC via PC2-mediated cleavage. Hippocampus was weighed and sonicated in $1 \mathrm{~mL}$ lysis buffer $(0.1 \mathrm{M}$ sodium acetate $\mathrm{pH} 5.5$; 1\% TritonX-100, $1 \mu$ M E64 (Sigma-Aldrich), $1 \mu \mathrm{g} / \mathrm{ml}$ pepstatin (Sigma-Aldrich), and $1 \mathrm{mM}$ phenylmethylsulfonyl fluoride (PMSF). The volume of buffer was adjusted to give tissue concentration $10 \mathrm{mg} / \mathrm{ml}$. After centrifugation for $10 \mathrm{~min}$ at $10,000 \mathrm{~g}$, supernatant was used for analysis of enzyme activity. Samples and reagents were kept on ice at all times. Test tubes were prepared for the measurement of enzymatic activity with final assay volume $200 \mu \mathrm{L}$, containing $50 \mu \mathrm{L}$ supernatant, $0,1 \mathrm{M}$ sodium acetate $(\mathrm{pH} 5.5)$, and $2.5 \mathrm{mM}$ calcium chloride and $0.25 \%$ TritonX-100. In order to test specificity, the synthetic peptide (7B2-CT), which corresponds to the C-terminal portion of human 7B2 (residues 155-185) was added to half of the tubes at $30 \mu \mathrm{M}$ final concentration and tubes were incubated for $15 \mathrm{~min}$ at $37^{\circ} \mathrm{C}$. Then the substrate p-Glu-Arg-Thr-LysArg-AMC (Sigma-Aldrich, final concentration $0.2 \mathrm{mM}$ ) was added to all tubes. Substrate was first dissolved in DMSO; the final concentration of DMSO in the reaction mix was $2 \%$. The reaction was $17 \mathrm{~h}$ long at $37^{\circ} \mathrm{C}$. The fluorescence of disengaged aminomethylcoumarin was measured using fluorescence - luminescence spectrophotometer (Luminescence Spectophometer LS50B, Perkin Elmer) with excitation at $380 \mathrm{~nm}$ and emission at $460 \mathrm{~nm}$. Control samples without enzyme and substrate were used as blanks. Specific PC2 activity was calculated as difference of total activity of the reaction and the activity in the presence of 7B2-CT peptide. Activity in the presence of $7 \mathrm{~B} 2-\mathrm{CT}$ was approximately $25-30 \%$ of total activity.

\section{Enzymatic Activity of Carboxypeptidase E (CPE)}

The method is based on the cleavage of the terminal arginine from the substrate using a fluorescence spectrophotometer developed by Fricker et al. (1996). Hippocampus was dissected, weighed, and homogenized in $2 \mathrm{ml}$ lysis buffer $(0.1 \mathrm{M}$ NaAc, $\mathrm{pH}$ 5.5, $1 \mathrm{mM}$ PMSF). For measuring carboxypeptidase E (CPE) activity, $25 \mu \mathrm{L}$ of the homogenate was added to $50 \mathrm{mM} \mathrm{NaAc}$ buffer ( $\mathrm{pH}$ 5.5), containing $0.01 \%$ Triton X100 and $200 \mu \mathrm{M}$ dansyl - Phe - Ala - Arg substrate in final volume of $250 \mu \mathrm{L}$. In addition, reaction mix contained either $1 \mathrm{mM} \mathrm{CoCl} 2$ or $1 \mu \mathrm{M}$ guanidinoethylmercaptosuccinic acid (GEMSA). After incubation at $37^{\circ} \mathrm{C}$ for $30-60 \mathrm{~min}, 100 \mu \mathrm{L}$ of $0.5 \mathrm{M} \mathrm{HCl}$ was added to stop the reaction and $2 \mathrm{~mL}$ of chloroform was added to extract dansyl - Phe - Ala. Tubes were mixed and centrifuged at $500 \times g$ for $2 \mathrm{~min}$. The amount of product was determined by measuring the fluorescence (excitation $350 \mathrm{~nm}$, emission $500 \mathrm{~nm}$ ) in the chloroform layer. CPE activity is defined as the difference between activity measured in the presence of $\mathrm{Co}^{2+}$ (activates CPE) and in the presence of GEMSA (inhibits $\mathrm{CPE}$ ). Non- specific fluorescence was measured in the absence of the tissue extract. All measurements were done in duplicates.

\section{Western Blot Analysis}

Western Blot analysis for PC2 was done using NuPAGE system (Life Technologies) according to manufacturer's guidelines.

Membranes with transferred proteins were blocked for $1 \mathrm{~h}$ in $3 \%$ BSA in PBS. Thereafter, the membranes were incubated with primary antibody overnight at $4^{\circ} \mathrm{C}$ and were rinsed six times in Milli-Q water. Membranes were incubated with secondary antibody for $1 \mathrm{~h}$ at room temperature and washed six times in Milli-Q water. Membranes were washed once for 20 min in PBS containing 0.1\% Tween-20. Antibody detection was performed using the LI-COR Odyssey CLx system (LICOR Biotechnologies). Images were converted to grayscale and quantification was performed using Image Studio Lite v 3.1.4 (LI-COR Biotechnologies). A commercial anti-PC2 antibody (Thermo-Scientific, dilution 1:200) was used to detect active isoform of PC2 (mass $69 \mathrm{kDa}$ ) and proPC2 (mass $72 \mathrm{kDa}$ ). The secondary antibody was Alexa-790 conjugated donkey anti rabbit (Jackson ImmunoResearch Laboratories, Inc., dilution $1: 40,000)$.

\section{RNA Isolation, cDNA Synthesis and Quantitative Real-Time PCR}

Samples were put on ice and homogenized with $200 \mu \mathrm{L}$ Trizol (Trizol ${ }^{\circledR}$ Reagent, Invitrogen, USA) when the tissue was slightly thawed. Samples were incubated at room temperature for $5 \mathrm{~min}$, chloroform was added and tubes were shaken for $15 \mathrm{sec}$. Samples were again incubated for $2 \mathrm{~min}$ at room temperature. Samples were centrifuged for $15 \mathrm{~min}, 12,000 \mathrm{~g}$ at $4^{\circ} \mathrm{C}$. The upper water phase was removed to a new $1.5 \mathrm{~mL}$ tube and isopropanol in half of the Trizol volume was added. Tubes were turned to mix carefully and incubated for $10 \mathrm{~min}$ at room temperature. Samples were centrifuged for $10 \mathrm{~min}, 12,000 \mathrm{~g}$ at $4^{\circ} \mathrm{C}$. Supernatant was taken away carefully and $1 \mathrm{~mL}$ of ice-cold $75 \% \mathrm{EtOH}$ was added to RNA. Tubes were centrifuged for $10 \mathrm{~min}, 10,000 \mathrm{~g}$, at $4^{\circ} \mathrm{C}$. Supernatant was removed carefully and tubes were left to dry until all the EtOH was evaporated. $250 \mu \mathrm{L} \mathrm{MQ}$ was added and RNA was frozen at $-80^{\circ} \mathrm{C}$. Before freezing the samples, RNA quality control was performed using Nanodrop. The 260/230 and 260/280 ratios were around 2.00 .

One microgram of total RNA of each sample with random hexamers (Applied Biosystems) and SuperScript ${ }^{\mathrm{TM}}$ III Reverse Transcriptase (Invitrogen, USA) were used for the first strand cDNA synthesis. Thermal cycling was performed using $7900 \mathrm{HT}$ Fast Real- time PCR system (Applied Biosystems) at $95^{\circ} \mathrm{C}$ for $10 \mathrm{~min}$, then $40 \mathrm{cycles}$ at $95^{\circ} \mathrm{C}$ for $15 \mathrm{sec}$ and $60^{\circ} \mathrm{C}$ for $1 \mathrm{~min}$. Probes were designed from exon-exon junctions eliminating the possibility of genomic DNA contamination. Hprtl was used as housekeeper gene as it is a reliable reference gene.

For RT-PCR, each sample was performed in four parallel reactions. The experiment was repeated two times and a negative control was used. The amplification curves of the housekeeping gene, PC2 and 7B2 were similar and the amount for each transcript was calculated using standard curve of cycle threshold for serial dilutions of the sample and normalized to Hprt1 expression. 


\section{Radioimmunoassay (RIA)}

Acid extracts $(0.1 \mathrm{M} \mathrm{HCl})$ were prepared from tissues by homogenizing in 200 (pituitary) or $1 \mathrm{ml}$ (hippocampus) of ice-cold $0.1 \mathrm{M} \mathrm{HCl}$. The samples were centrifuged at 15,000 $\mathrm{g}$ for $15 \mathrm{~min}$ and the clear supernatant was lyophilized. Samples were reconstituted in $0.5 \mathrm{ml}$ of RIA buffer $(-0.1 \mathrm{M}$ sodium phosphate, $\mathrm{pH} 7.4$, with $50 \mathrm{mM}$ sodium chloride, and $0.1 \%$ BSA and azide), shaken for $30 \mathrm{~min}$ at room temperature, centrifuged, and $100 \mu \mathrm{L}$ duplicates measured for 7B2 using a sensitive RIA employing an antiserum to residues 23-39 (Zhu and Lindberg, 1995).

\section{Protein Measurement}

Micro BCA ${ }^{\mathrm{TM}}$ Protein Assay Kit (Thermo Scientific) was used for the protein measurement and the analysis was done according to the manufacturer's protocol.

\section{Statistical Analysis}

Unpaired two-tailed Student's $t$-test was used to compare experimental groups. A $P$-value of less than 0.05 was considered as statistically significant. Data are presented as mean \pm SEM.

\section{Results}

\section{Peptidomic Study}

One hundred and twenty-six individual peptides with sequence length of 8-24 amino acids were identified (Supplementary Table S1). The molecular weight of identified peptides was in the range from 757 to $2817 \mathrm{Da}$. Most of the identified peptides were derived from 11 precursor sequences: galanin; orexin/hypocretin; neuropeptide Y; proprotein convertase subtilisin/kexin type 1 inhibitor; preprodynorphin; proenkephalin-A; melaninconcentrating hormone; prepronociceptin; neuroendocrine protein 7B2; substance $\mathrm{P}$ and teneurin-1.

The levels of 10 peptides were found to be different in Wfs 1 KO versus wild-type mice (Table 1). The peptide with the biggest fold change was little-LEN, a peptide derived from proSAAS. Little-LEN is cleaved from proSAAS in a PC2 dependent manner (Figure 2). As the level of little-LEN was 25 times higher in

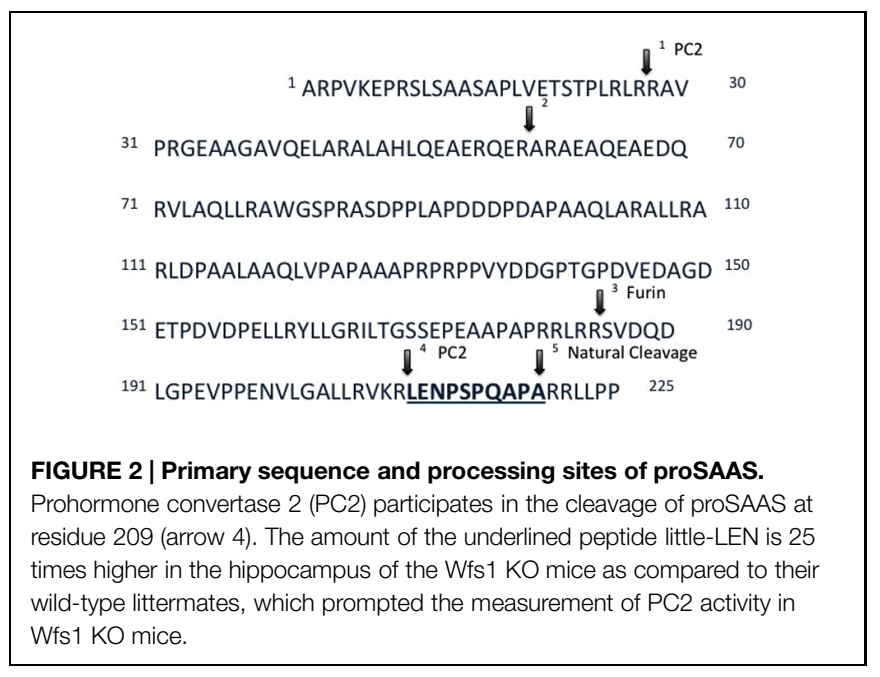

Wfs $1 \mathrm{KO}$ mice, we decided to measure the activity of PC2 in the hippocampus of these mice.

\section{Prohormone Convertase 2 Activity Measurement}

The activity of PC2 in the hippocampus of Wfs1 KO mice was measured using a fluorogenic substrate coupled with a specific PC2 inhibitor. PC2 activity was significantly higher in Wfs1 $\mathrm{KO}$ mice compared to wild-type mice (Figure 3A), which is in accordance with the elevated little-LEN peptide levels in Wfs 1 $\mathrm{KO}$ mice. PC2 participates in the cleavage of proSAAS at residue 209 (Sayah et al., 2001), thus producing little-LEN (Figure 2, arrow 4).

As the activity of PC2 was significantly higher in Wfs1 KO animals, we measured the protein and mRNA levels of PC2 as well to see whether the increased activity was due to elevated mRNA or protein levels. 7B2 performs a dual function for PC2: while the C-terminal part of 7B2 inhibits active PC2, the remainder of the protein is needed to obtain active PC2 from proPC2. Therefore, we also measured $\mathrm{mRNA}$ and protein levels of 7B2.

\begin{tabular}{|c|c|c|c|c|c|c|}
\hline \multirow[t]{2}{*}{ Penk } & YGGFMRSL & 929.4429 & -1.08 & $\begin{array}{l}\text { Met-enkephalin- } \\
\text { Arg-Gly-Leu }\end{array}$ & 4.98 & 0.0065 \\
\hline & LRGNKSIS & 873.5032 & -0.82 & & 3.05 & 0.0069 \\
\hline & DSDSEAYPEDSERR & 1654.671 & 0.38 & & 1.47 & 0.018 \\
\hline Pcsk1n & SVDQDLGPEVPPENVLGAL & 1947.979 & -0.94 & PEN-19 & 0.32 & 0.027 \\
\hline Pcsk1n & SVDQDLGPEVPPENVLGALLRV & 2316.233 & -4.33 & PEN & 0.22 & 0.036 \\
\hline Pcsk1n & SVDQDLGPEVPPENVLGA & 1834.895 & -0.84 & PEN-18 & 0.56 & 0.040 \\
\hline Scg5 & VEYPAHQAMNLVGPQSIEG & 2038.978 & -1.46 & & 0.52 & 0.041 \\
\hline Penk & PEWWMDYQ & 1153.454 & -0.62 & Peptide-E & 0.40 & 0.05 \\
\hline
\end{tabular}


A

PC2 activity

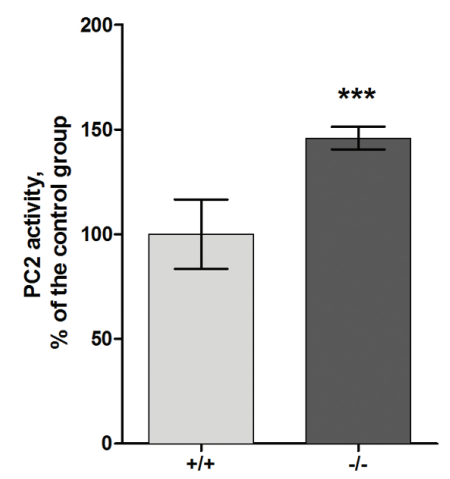

Wfs1 genotype

C

Gene expression PC2

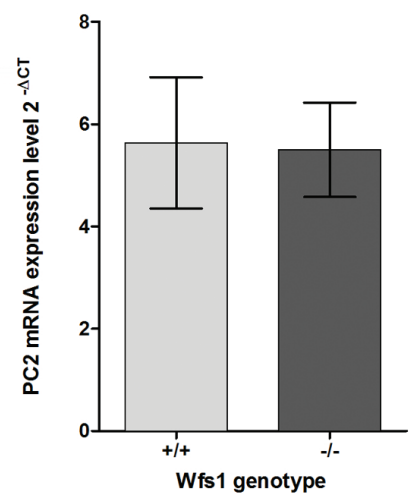

E

Protein level of PC2

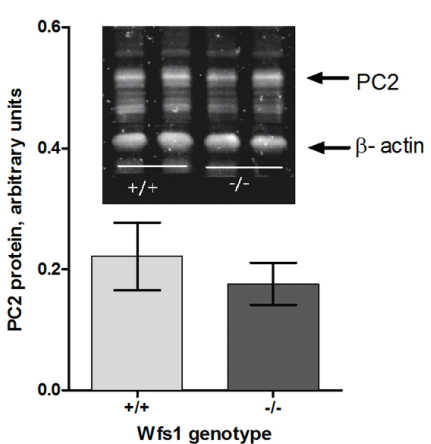

FIGURE 3 | Prohormone convertase 2 in the hippocampus of Wfs1 mice. (A) PC2 activity is higher in Wfs1 $\mathrm{KO}$ mice $(149.9 \pm 2.3 \%, n=8$, $\left.{ }^{* * *} p<0.0001\right)$ than wild-type mice $(100.0 \pm 7.0 \%, n=8)$. The activity of PC2 is shown as percentage of the wild-type group. PC2 activity in the hippocampus of wild-type mice was $12.1 \mathrm{pmol} / \mathrm{mg}$ protein/min. Activity in the presence of 7B2-CT was approximately $25-30 \%$ of total activity. (B) Radioimmunoassay (RIA) for measuring 7B2 protein level. Immunoreactivity was slightly higher in wild-type mice (109.5 $\pm 6.0, n=8)$ than in Wfs1 $\mathrm{KO}$ mice $(97,1 \pm 2,9, n=8)$, though these results are not significantly different. (C,D) mRNA levels of PC2

\section{B $\quad$ RIA of 7B2}

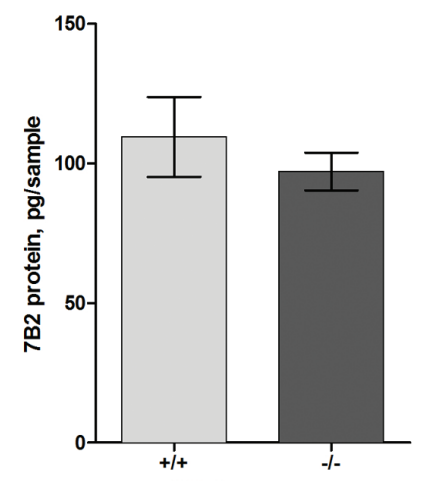

Wfs1 genotype

\section{Gene expression 7B2}

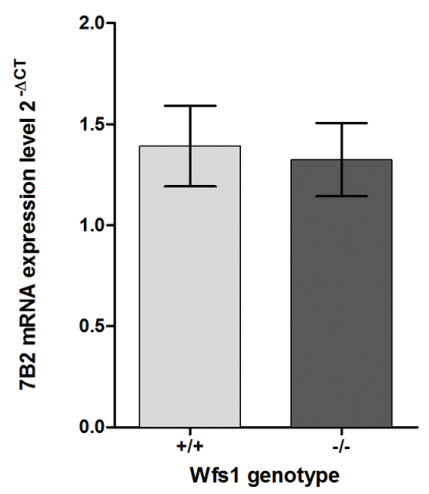

$\mathbf{F}$

\section{CPE activity}

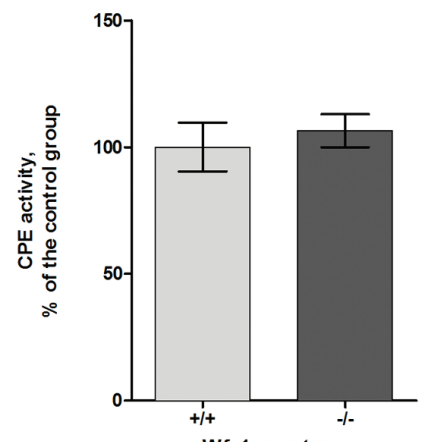

and 7B2, respectively, were measured with GPCR. PC2 mRNA expression levels were similar in both groups (5.63 $\pm 0.53, n=7$ in wild-type mice and $5.50 \pm 0.39, n=8$ in Wfs1 KO mice). 7B2 mRNA expression levels were similar in both groups $(1.39 \pm 0.08, n=8$ in wild- type mice and $1.32 \pm 0.08, n=8$ in Wfs1 $\mathrm{KO}$ mice). (E) Protein levels of PC2 were similar in Wfs1 $\mathrm{KO}$ mice $(0.77 \pm 0.14, n=8, p=0.27)$ and in wild-type mice $(1.00 \pm 0.10, n=8)$. (F) Carboxypeptidase $\mathrm{E}$ (CPE) activity was similar in Wfs $1 \mathrm{KO}$ mice $(106.5 \pm 2.7 \%, N=8)$ and wild-type mice $(100.0 \pm 4.01 \%, n=8)$. Student's $t$-test was used for statistical analysis. 


\section{PC2 and 7B2 Protein and mRNA Levels}

Prohormone convertase 2 and 7B2 protein levels were measured with Western blot analysis. There was no difference in PC2 protein levels between the groups (Figure 3E). As Western blotting is not sensitive enough to measure $7 \mathrm{~B} 2$ protein levels, RIA was used for that purpose. There was no difference in $7 \mathrm{~B} 2$ protein levels in Wfs1 KO and wild-type mice (Figure 3B). There was also no difference in mRNA levels of PC2 and 7B2 (Figures 3C,D).

In sum, we found no significant difference in the protein and mRNA levels of both PC2 and 7B2, yet the activity of PC2 was significantly higher and so were the levels of peptide little-LEN, a product thought to be generated by PC2.

\section{CPE Activity}

To obtain active neuropeptides and peptide hormones, two sets of enzymes are needed. First, PCs, like PC2, cleave the precursor at specific sites to generate peptides with C-terminal basic residues; these intermediates are then cut by CPE to remove basic residues (Fricker et al., 1996). Therefore we measured the activity levels of CPE with fluorescence spectrophotometry. We found no significant difference of CPE activity levels in the hippocampus of Wfs1 $\mathrm{KO}(106.5 \pm 2.7 \%, N=8)$ and wild-type mice $(100.0 \pm 4.01 \%, N=8$, Figure $3 F)$.

\section{Discussion}

The Wfs 1 protein is highly expressed in pancreatic beta-cells, and the role of Wfs 1 in the processing and secretion of insulin is relatively well studied (Hatanaka et al., 2011). Wfs1 is also expressed in the brain, and the highest levels of this protein are found in the limbic structures, amygdala, second layer of the cortex and hippocampus (Luuk et al., 2008). Heterozygous mutations in WFS1 increase the risk of psychiatric disorders without causing WS (Swift et al., 1998; Swift and Swift, 2000, 2005), although this view has been challenged (Kato et al., 2003; Martorell et al., 2003). Nevertheless, a recent meta-analysis of genome-wide expression studies revealed WFS1 mRNA to be significantly elevated in the prefrontal cortex of patients with bipolar disorder (Seifuddin et al., 2013). Therefore, Wfs1 seems to be important in the regulation of brain function in addition to its well-known role in neurodegeneration. To the best of our knowledge, there is only one study connecting WFS1 with peptide processing in the brain, in which lack of vasopressin processing was revealed in the hypothalamus of WS patients (Gabreels et al., 1998). Therefore, the aim of this study was to evaluate the peptide profile in the hippocampus of Wfs1 KO mice using a peptidomic approach. The hippocampus was chosen as this region shows high expression levels of Wfs1 (Luuk et al., 2008).

In this study we used mice of the age of 3 months. At this age Wfs1 KO animals already display characteristic phenotype. The growth of Wfs1 KO mice stops at age of 2 months while wild-type mice continue to grow, thus, body weight of Wfs1 $\mathrm{KO}$ animals is smaller than body weight of wild-type animals at the age of 3 months (Luuk et al., 2009; Punapart et al.,
2014). Wfs1 KO mice used in this study are also smaller than their wild-type littermates, indicating functional consequence of Wfs 1 invalidation. The basal blood glucose levels are similar for both genotypes even at the age of 6 months (Terasmaa et al., 2011), while Wfs1 KO animals display glucose intolerance already at the age of 2-3 months (Luuk et al., 2009). Although glucose tolerance in Wfs1 KO mice was not measured in this study, we can presume that 3 months old Wfs1 KO mice used in this study display glucose intolerance that reflect a lack of Wfs 1 function. WS is a severe disorder that is characterized by optic atrophy, deafness, and diabetes (Rigoli et al., 2011). Glucose intolerance of Wfs1 KO mice seem to correlate well with the human condition. However, other characteristics of WS may take longer time to manifest in mice and therefore, direct comparison of mice with patients suffering from WS is not straightforward.

A mass-spectrometric approach to identify individual peptides was used in this study. 126 individual peptides were identified and levels of 10 peptides were statistically significantly dependent on the Wfs1 genotype.

The peptide with the largest increase was little-LEN, a product of cleavage of proSAAS (the Pcsk1n gene product). The closely related peptide big-LEN was recently found to be an agonist for hypothalamic G protein-coupled receptor GPR171, which plays a role in central regulation of feeding and metabolism (Gomes et al., 2013). However, little-LEN has no activity at GPR171 (Gomes et al., 2013). Little-LEN is cleaved from proSAAS in a PC2- and furin-dependent manner (Sayah et al., 2001) (Figure 2), we therefore evaluated the activity of PC2 in Wfs1 $\mathrm{KO}$ mice. Our results indicate that PC2 activity is upregulated in the hippocampus of Wfs $1 \mathrm{KO}$ mice. This is in contrast with a previous report, where lack of vasopressin processing was associated with the absence of PC2- and 7B2-immunoreactivity in the paraventricular nucleus of WS patients (Gabreels et al., 1998). Also, the protein level of PC2 was not changed in the pancreatic beta-cells of Wfs1-null mice (Hatanaka et al., 2011). Thus, PC2 might be differentially regulated by Wfs1 in different cell types. In this study we found no alterations in protein or mRNA levels of PC2 and its chaperone 7B2 in the hippocampus of Wfs1 KO mice. As the activity of PC2 is increased, there is a possibility that Wfs1 regulates enzymatic activity of PC2 via a completely different mechanism rather than simply regulating its expression level.

Prohormone convertase 2 is found in neuroendocrine cells, which contain a regulatory secretory pathway. These cells are capable of processing different prohormones like provasopressin, proinsulin, proenkephalin, prosomatostatin, pro-TRH, proopiomelanocortin (POMC) and many others (Benjannet et al., 1991; Breslin et al., 1993; Brakch et al., 1995; Friedman et al., 1995). The main task of PC2 is proteolytic processing of neuropeptide and peptide hormone precursors. The PCs are widely expressed in the brain cortex, hippocampus, and hypothalamus (Schafer et al., 1993). PC2 itself is activated via proteolytic cleavage; immature $75-\mathrm{kDa}$ proPC2 is cut to yield active $68-\mathrm{kDa}$ PC2. Such cleavage is not necessary for PC2 secretion, but is needed for its activation (Taylor et al., 1997). PC2 differs from all other PCs in its requirement for interaction 


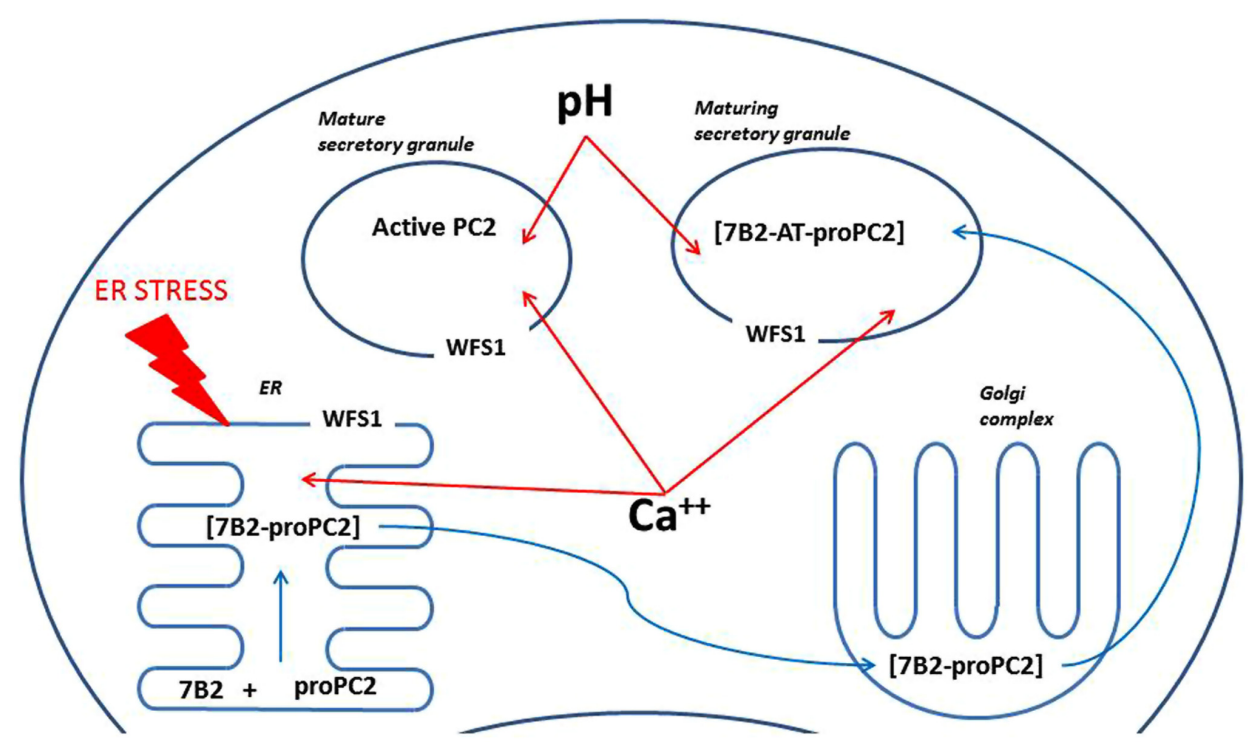

FIGURE 4 | A scheme illustrating possible mechanisms of regulation of PC2 by Wfs1. ProPC2 with its chaperon 7B2 are transported into endoplasmic reticulum (ER), where they form a complex, which exits the ER without PC2 propeptide cleavage. Thereafter 7B2- proPC2 complex enters Golgi complex, where 7B2 is internally cleaved into $21 \mathrm{kDa}$ amino terminal part (7B2-AT) and 31 amino acids long carboxy-terminal part. Then 7B2-AT-proPC2 complex is transported into maturing secretory granules. In the maturing secretory granules PC2 propeptide is cleaved to an active PC2. Wfs1 protein is localized in the membrane of ER and also secretory granules, where it regulates $\mathrm{Ca}^{++}$levels and $\mathrm{pH}$. In turn, $\mathrm{pH}$ and $\mathrm{Ca}^{++}$are known to regulate activity of PC2. In addition, lack of Wfs 1 function leads to increased ER stress, which can alter proper folding of proPC2 and 7B2 in the ER. with the neuroendocrine-specific protein 7B2 to generate active PC2 (Zhu and Lindberg, 1995). Interaction between proPC2 and 7B2 is complex and occurs in different cellular compartments (Figure 4; Muller and Lindberg, 1999). The 7B2 protein was first isolated from the pituitary gland in the 1980s (Martens, 1988). It is found in the central nervous system and endocrine tissues (Seidah et al., 1983). 7B2 is synthesized as 185 amino acid precursor protein and during passage through the secretory pathway it is cut into two fragments - amino-terminal (21-kDa) and carboxyl-terminal part (7B2-CT; Laurent et al., 2002). The amino-terminal part is necessary to activate proPC2 (Zhu and Lindberg, 1995); and at the same time, the 7B2-CT peptide is a highly selective PC2 activity inhibitor (van Horssen et al., 1995). However, we found no alterations in mRNA and protein levels of 7B2 in the hippocampus of Wfs1 KO mice (Figure 3D).

The activity of PC2 is further regulated in several different ways. Acidification of secretory granules is required for proper functioning of PC2 (Hatanaka et al., 2011) and acidification of secretory granules in pancreatic beta-cells is Wfs 1 dependent (Hatanaka et al., 2011). However, the effect of Wfs1 invalidation on acidification of secretory granules in the brain is unknown. In addition to the $\mathrm{pH}$, maturation of $\mathrm{PC} 2$ is also regulated by calcium levels (Shennan et al., 1995) and Wfs1 is well known to be involved in regulation of intracellular calcium (Osman et al., 2003). Also, the activity of 7B2 is regulated via its phosphorylation (Lee et al., 2006). We suggest that Wfs 1 can regulate activity of PC2 via any of these mechanisms in the brain. However, the precise mechanism of involvement of Wfs 1 in the regulation of PC2 activity in the brain is unknown and needs further attention. As all of the proposed mechanisms of regulation of PC2 are on the intracellular level, it is also necessary to investigate whether PC2 and Wfs1 are co-expressed in the same cells in the brain.

The peptide whose level showed the next largest Wfs1dependent change was Met-enkephalin-Arg-Gly-Leu, a product of proenkephalin cleavage (Table 1). This peptide showed strongly reduced levels in the hypothalamus of $\mathrm{PC} 2-\mathrm{KO}$ mice (Pan et al., 2006). In this study, we found that the level of Met-enkephalin-Arg-Gly-Leu was almost five times higher in the hippocampus of Wfs1 KO mice, thus, pointing to a higher activity of PC2. A higher level of this peptide further supports the increased activity of PC2 in the hippocampus of Wfs1 KO mice.

\section{Conclusion}

We identified 126 individual peptide fragments in mouse hippocampal extracts. Analysis of the relative abundance of these peptides revealed alterations in the processing of proSAAS and proenkephalin in the hippocampus of Wfs1 KO mice, which is most likely caused by an increase in the activity of PC2. The increased activity of PC2 in Wfs1 KO mice is not a result of increased levels of the PC2 protein or its chaperone 7B2. Thus, the role of Wfs1 in the regulation of $\mathrm{PC} 2$ activity requires further investigation.

\section{Author Contributions}

KT, AT, SK, and EV conceived the study, SergoK performed massspectrometry analysis, KT and AT extracted peptides, measured 
enzymatic activity and performed Western blot analysis. SergoK, $\mathrm{AT}$, and $\mathrm{KT}$ analyzed the data, KT and AT wrote the manuscript. All the authors have read and approved the final version of the manuscript.

\section{Acknowledgments}

This study was supported by grants PUT784 (AT), IUT2041 (EV), and IUT20-46 (SK) from Estonian Science Agency.

\section{References}

Benjannet, S., Rondeau, N., Day, R., Chretien, M., and Seidah, N. G. (1991). PC1 and PC2 are proprotein convertases capable of cleaving proopiomelanocortin at distinct pairs of basic residues. Proc. Natl. Acad. Sci. U.S.A. 88, 3564-3568. doi: 10.1073/pnas.88.9.3564

Brakch, N., Galanopoulou, A. S., Patel, Y. C., Boileau, G., and Seidah, N. G. (1995). Comparative proteolytic processing of rat prosomatostatin by the convertases PC1, PC2, furin, PACE4 and PC5 in constitutive and regulated secretory pathways. FEBS Lett. 362, 143-146. doi: 10.1016/0014-5793(95)00229-3

Breslin, M. B., Lindberg, I., Benjannet, S., Mathis, J. P., Lazure, C., and Seidah, N. G. (1993). Differential processing of proenkephalin by prohormone convertases 1(3) and 2 and furin. J. Biol. Chem. 268, 27084-27093.

Cox, J., and Mann, M. (2008). MaxQuant enables high peptide identification rates, individualized p.p.b.-range mass accuracies and proteome-wide protein quantification. Nat. Biotechnol. 26, 1367-1372. doi: 10.1038/nbt.1511

Crawford, J., Zielinski, M. A., Fisher, L. J., Sutherland, G. R., and Goldney, R. D. (2002). Is there a relationship between Wolfram syndrome carrier status and suicide? Am. J. Med. Genet. 114, 343-346. doi: 10.1002/ajmg.10256

Evans, K. L., Lawson, D., Meitinger, T., Blackwood, D. H., and Porteous, D. J. (2000). Mutational analysis of the Wolfram syndrome gene in two families with chromosome 4p-linked bipolar affective disorder. Am. J. Med. Genet. 96, 158-160. doi: 10.1002/(SICI)1096-8628(20000403)96:2<158::AIDAJMG6>3.0.CO;2-8

Frese, C. K., Boender, A. J., Mohammed, S., Heck, A. J., Adan, R. A., and Altelaar, A. F. (2013). Profiling of diet-induced neuropeptide changes in rat brain by quantitative mass spectrometry. Anal. Chem. 85, 4594-4604. doi: $10.1021 / \mathrm{ac} 400232 \mathrm{y}$

Fricker, L. D., Berman, Y. L., Leiter, E. H., and Devi, L. A. (1996). Carboxypeptidase E activity is deficient in mice with the fat mutation. Effect on peptide processing. J. Biol. Chem. 271, 30619-30624. doi: 10.1074/jbc.271.48.30619

Friedman, T. C., Loh, Y. P., Cawley, N. X., Birch, N. P., Huang, S. S., Jackson, I. M., et al. (1995). Processing of prothyrotropin-releasing hormone (Pro-TRH) by bovine intermediate lobe secretory vesicle membrane PC1 and PC2 enzymes. Endocrinology 136, 4462-4472.

Gabreels, B. A., Swaab, D. F., De Kleijn, D. P., Dean, A., Seidah, N. G., Van De Loo, J. W., et al. (1998). The vasopressin precursor is not processed in the hypothalamus of Wolfram syndrome patients with diabetes insipidus: evidence for the involvement of PC2 and 7B2. J. Clin. Endocrinol. Metab. 83, 4026-4033. doi: 10.1210/jcem.83.11.5158

Gomes, I., Aryal, D. K., Wardman, J. H., Gupta, A., Gagnidze, K., Rodriguiz, R. M., et al. (2013). GPR171 is a hypothalamic G protein-coupled receptor for BigLEN, a neuropeptide involved in feeding. Proc. Natl. Acad. Sci. U.S.A. 110, 16211-16216. doi: 10.1073/pnas.1312938110

Hatanaka, M., Tanabe, K., Yanai, A., Ohta, Y., Kondo, M., Akiyama, M., et al. (2011). Wolfram syndrome 1 gene (WFS1) product localizes to secretory granules and determines granule acidification in pancreatic \{beta\}-cells. Hum. Mol. Genet. 20, 1274-1284. doi: 10.1093/hmg/ddq568

Hofmann, S., Philbrook, C., Gerbitz, K. D., and Bauer, M. F. (2003). Wolfram syndrome: structural and functional analyses of mutant and wild-type wolframin, the WFS1 gene product. Hum. Mol. Genet. 12, 2003-2012. doi: $10.1093 / \mathrm{hmg} / \mathrm{ddg} 214$

Kato, T., Iwamoto, K., Washizuka, S., Mori, K., Tajima, O., Akiyama, T., et al. (2003). No association of mutations and mRNA expression of WFS1/wolframin
We sincerely thank Iris Lindberg (University of Maryland) for performing the 7B2 RIA assay and for the critical reading of the manuscript.

\section{Supplementary Material}

The Supplementary Material for this article can be found online at: http://journal.frontiersin.org/article/10.3389/fnmol. 2015.00045

with bipolar disorder in humans. Neurosci. Lett. 338, 21-24. doi: 10.1016/S03043940(02)01334-4

Laurent, V., Kimble, A., Peng, B., Zhu, P., Pintar, J. E., Steiner, D. F., et al. (2002). Mortality in 7B2 null mice can be rescued by adrenalectomy: involvement of dopamine in ACTH hypersecretion. Proc. Natl. Acad. Sci. U.S.A. 99, 3087-3092. doi: $10.1073 /$ pnas.261715099

Lee, S. N., Hwang, J. R., and Lindberg, I. (2006). Neuroendocrine protein 7B2 can be inactivated by phosphorylation within the secretory pathway. J. Biol. Chem. 281, 3312-3320. doi: 10.1074/jbc.M506635200

Li, Q. L., Naqvi, S., Shen, X., Liu, Y. J., Lindberg, I., and Friedman, T. C. (2003). Prohormone convertase 2 enzymatic activity and its regulation in neuroendocrine cells and tissues. Regul. Pept. 110, 197-205. doi: 10.1016/S01670115(02)00207-0

Luuk, H., Koks, S., Plaas, M., Hannibal, J., Rehfeld, J. F., and Vasar, E. (2008). Distribution of Wfs1 protein in the central nervous system of the mouse and its relation to clinical symptoms of the Wolfram syndrome. J. Comp. Neurol. 509, 642-660. doi: 10.1002/cne.21777

Luuk, H., Plaas, M., Raud, S., Innos, J., Sutt, S., Lasner, H., et al. (2009). Wfs1-deficient mice display impaired behavioural adaptation in stressful environment. Behav. Brain Res. 198, 334-345. doi: 10.1016/j.bbr.2008.11.007

Martens, G. J. (1988). Cloning and sequence analysis of human pituitary cDNA encoding the novel polypeptide 7B2. FEBS Lett. 234, 160-164. doi: 10.1016/0014-5793(88)81324-3

Martorell, L., Zaera, M. G., Valero, J., Serrano, D., Figuera, L., Joven, J., et al. (2003). The WFS1 (Wolfram syndrome 1) is not a major susceptibility gene for the development of psychiatric disorders. Psychiatr. Genet. 13, 29-32. doi: 10.1097/01.ypg.0000056176.32550.ec

Muller, L., and Lindberg, I. (1999). The cell biology of the prohormone convertases PC1 and PC2. Prog Nucleic Acid Res. Mol. Biol. 63, 69-108. doi: 10.1016/S00796603(08)60720-5

Noormets, K., Koks, S., Kavak, A., Arend, A., Aunapuu, M., Keldrimaa, A., et al. (2009). Male mice with deleted Wolframin (Wfs1) gene have reduced fertility. Reprod. Biol. Endocrinol. 7, 82. doi: 10.1186/1477-7827-7-82

Noormets, K., Koks, S., Muldmaa, M., Mauring, L., Vasar, E., and Tillmann, V. (2011). Sex differences in the development of diabetes in mice with deleted wolframin (WFS1) gene. Exp. Clin. Endocrinol. Diabetes 19, 271-275. doi: 10.1055/s-0030-1265163

Osman, A. A., Saito, M., Makepeace, C., Permutt, M. A., Schlesinger, P., and Mueckler, M. (2003). Wolframin expression induces novel ion channel activity in endoplasmic reticulum membranes and increases intracellular calcium. J. Biol. Chem. 278, 52755-52762. doi: 10.1074/jbc.M310331200

Pan, H., Che, F. Y., Peng, B., Steiner, D. F., Pintar, J. E., and Fricker, L. D. (2006). The role of prohormone convertase-2 in hypothalamic neuropeptide processing: a quantitative neuropeptidomic study. J. Neurochem. 98, 17631777. doi: 10.1111/j.1471-4159.2006.04067.x

Punapart, M., Eltermaa, M., Oflijan, J., Sutt, S., Must, A., Koks, S., et al. (2014). Effect of chronic valproic Acid treatment on hepatic gene expression profile in wfs1 knockout mouse. PPAR Res. 2014, 349525. doi: 10.1155/2014/ 349525

Rappsilber, J., Mann, M., and Ishihama, Y. (2007). Protocol for micro-purification, enrichment, pre-fractionation and storage of peptides for proteomics using StageTips. Nat. Protoc. 2, 1896-1906. doi: 10.1038/nprot.2007.261

Rigoli, L., Lombardo, F., and Di Bella, C. (2011). Wolfram syndrome and WFS1 gene. Clin. Genet. 79, 103-117. doi: 10.1111/j.1399-0004.2010.01522.x 
Sayah, M., Fortenberry, Y., Cameron, A., and Lindberg, I. (2001). Tissue distribution and processing of proSAAS by proprotein convertases. J. Neurochem. 76, 1833-1841. doi: 10.1046/j.1471-4159.2001.00165.x

Schafer, M. K., Day, R., Cullinan, W. E., Chretien, M., Seidah, N. G., and Watson, S. J. (1993). Gene expression of prohormone and proprotein convertases in the rat CNS: a comparative in situ hybridization analysis. J. Neurosci. 13, 1258-1279.

Seidah, N. G., Hsi, K. L., De Serres, G., Rochemont, J., Hamelin, J., Antakly, T., et al. (1983). Isolation and NH2-terminal sequence of a highly conserved human and porcine pituitary protein belonging to a new superfamily. Immunocytochemical localization in pars distalis and pars nervosa of the pituitary and in the supraoptic nucleus of the hypothalamus. Arch. Biochem. Biophys. 225, 525-534. doi: 10.1016/0003-9861(83)90063-2

Seifuddin, F., Pirooznia, M., Judy, J. T., Goes, F. S., Potash, J. B., and Zandi, P. P. (2013). Systematic review of genome-wide gene expression studies of bipolar disorder. BMC Psychiatry 13:213. doi: 10.1186/1471-244X-13-213

Shennan, K. I., Taylor, N. A., Jermany, J. L., Matthews, G., and Docherty, K. (1995). Differences in $\mathrm{pH}$ optima and calcium requirements for maturation of the prohormone convertases PC2 and PC3 indicates different intracellular locations for these events. J. Biol. Chem. 270, 1402-1407. doi: 10.1074/jbc.270.3.1402

Strom, T. M., Hortnagel, K., Hofmann, S., Gekeler, F., Scharfe, C., Rabl, W., et al. (1998). Diabetes insipidus, diabetes mellitus, optic atrophy and deafness (DIDMOAD) caused by mutations in a novel gene (wolframin) coding for a predicted transmembrane protein. Hum. Mol. Genet. 7, 2021-2028. doi: $10.1093 / \mathrm{hmg} / 7.13 .2021$

Swift, M., and Swift, R. G. (2000). Psychiatric disorders and mutations at the Wolfram syndrome locus. Biol. Psychiatry 47, 787-793. doi: 10.1016/S00063223(00)00244-4

Swift, M., and Swift, R. G. (2005). Wolframin mutations and hospitalization for psychiatric illness. Mol. Psychiatry 10, 799-803. doi: 10.1038/sj.mp.4001681

Swift, R. G., Perkins, D. O., Chase, C. L., Sadler, D. B., and Swift, M. (1991). Psychiatric disorders in 36 families with Wolfram syndrome. Am. J. Psychiatry 148, 775-779. doi: 10.1176/ajp.148.6.775

Swift, R. G., Polymeropoulos, M. H., Torres, R., and Swift, M. (1998). Predisposition of Wolfram syndrome heterozygotes to psychiatric illness. Mol. Psychiatry 3, 86-91. doi: 10.1038/sj.mp.4000344

Takeda, K., Inoue, H., Tanizawa, Y., Matsuzaki, Y., Oba, J., Watanabe, Y., et al. (2001). WFS1 (Wolfram syndrome 1) gene product: predominant subcellular localization to endoplasmic reticulum in cultured cells and neuronal expression in rat brain. Hum. Mol. Genet. 10, 477-484. doi: 10.1093/hmg/ 10.5.477

Taylor, N. A., Shennan, K. I., Cutler, D. F., and Docherty, K. (1997). Mutations within the propeptide, the primary cleavage site or the catalytic site, or deletion of C-terminal sequences, prevents secretion of proPC2 from transfected COS-7 cells. Biochem. J. 321(Pt 2), 367-373. doi: 10.1042/bj3210367

Terasmaa, A., Soomets, U., Oflijan, J., Punapart, M., Hansen, M., Matto, V., et al. (2011). Wfs1 mutation makes mice sensitive to insulin-like effect of acute valproic acid and resistant to streptozocin. J. Physiol. Biochem. 67, 381-390. doi: 10.1007/s13105-011-0088-80

Torres, R., Leroy, E., Hu, X., Katrivanou, A., Gourzis, P., Papachatzopoulou, A., et al. (2001). Mutation screening of the Wolfram syndrome gene in psychiatric patients. Mol. Psychiatry 6, 39-43. doi: 10.1038/sj.mp. 4000787

van Horssen, A. M., Van Den Hurk, W. H., Bailyes, E. M., Hutton, J. C., Martens, G. J., and Lindberg, I. (1995). Identification of the region within the neuroendocrine polypeptide $7 \mathrm{~B} 2$ responsible for the inhibition of prohormone convertase PC2. J. Biol. Chem. 270, 14292-14296. doi: 10.1074/jbc.270.24. 14292

Wolfram, D. J., and Wagener, H. P. (1938). Diabetes mellitus and simple optic atrophy among siblings: report of four cases. Mayo Clin. Proc. 13, $715-718$.

Zhu, X., and Lindberg, I. (1995). 7B2 facilitates the maturation of proPC2 in neuroendocrine cells and is required for the expression of enzymatic activity. J. Cell Biol. 129, 1641-1650. doi: 10.1083/jcb.129.6.1641

Conflict of Interest Statement: The authors declare that the research was conducted in the absence of any commercial or financial relationships that could be construed as a potential conflict of interest.

Copyright (C) 2015 Tein, Kasvandik, Kõks, Vasar and Terasmaa. This is an openaccess article distributed under the terms of the Creative Commons Attribution License (CC BY). The use, distribution or reproduction in other forums is permitted, provided the original author(s) or licensor are credited and that the original publication in this journal is cited, in accordance with accepted academic practice. No use, distribution or reproduction is permitted which does not comply with these terms. 